Viso: Cadernos de estética aplicada

Revista eletrônica de estética

ISSN 1981-4062

No 25, jul-dez/2019

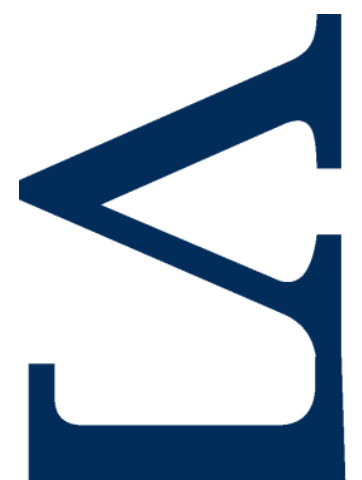

http://www.revistaviso.com.br/

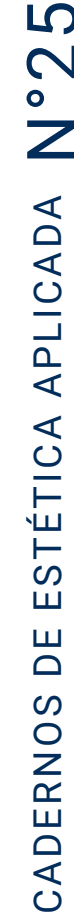

\title{
"E como melhor no fim trabalho perdido e silêncio": A experiência histórica de Fim de Partida, de Samuel Beckett
}

Daniel Gilly 


\section{RESUMO}

"E como melhor no fim trabalho perdido e silêncio": A experiência histórica de Fim de Partida, de Samuel Beckett

O trabalho propõe uma análise da peça teatral Fim de Partida, do autor irlandês Samuel Beckett, a partir da perspectiva da inserção da obra de arte em seu contexto histórico-filosófico. Assim, proponho uma leitura da obra como uma resposta aos procedimentos técnicos da ordem social capitalista da época e à proximidade da destruição causada pela Segunda Guerra Mundial. Essas condições históricas não necessariamente serão desenvolvidas como um tema na produção artística de Beckett, mas se refletem em sua obra a partir da elaboração de técnicas dramatúrgicas e de um esforço linguístico de criação voltados para a expressão de uma ordem social e política nova, na qual muitos dos pressupostos dramatúrgicos legados pela tradição precisam ser contestados e reformulados. Assim, nas construções dialógicas novas, na ideia de natureza como história e como decadência, na deformação física e espiritual das personagens, na violência anônima e indizível que cerca todo o palco, etc, o que se tenta expressar é um novo estatuto da linguagem e da racionalidade que não pode mais se apresentar dentro das convenções de uma construção dramática tradicional. Neste artigo, pretendo apresentar as novas possibilidades de expressão de uma condição histórica da humanidade através da obra beckettiana, assim como as eventuais limitações de ação e criação que foram colocadas por ela.

Palavras-chave

teatro; história; linguagem; natureza

\section{ABSTRACT \\ "And How Better in the End Labour Lost and Silence": The Historical Experience of Endgame, by Samuel Beckett}

This work proposes an analysis of the play Endgame, by Irish author Samuel Beckett, from the perspective of the insertion of the work of art in its historical-philosophical context. I propose a reading of the work as a response to the technical procedures of capitalist social order and to the proximity of the destruction caused by the World War II. These historical conditions won't necessarily be developed as a theme in Beckett's artistic production, but are reflected in his work as an elaboration of dramaturgical techniques and a creative linguistic effort destined to the expression of a new political and social order, where most of the dramaturgical assumptions transmitted by tradition needed to be contested and reformulated. This way, in the new dialogical constructions, in the idea of nature as history and decay, in the physical and spiritual deformation of the characters, in the anonymous and unspeakable violence that surrounds the stage, etc, there is an attempt to express a new statute of language and rationality that no longer can be presented according to the conventions of a traditional dramatic construction. In this article, I propose to present the new expressive possibilities of humanity's historical condition through the work of Beckett, as well as the eventual limits of action and creation brought by it.

Keywords

theater; history; language; nature 


\section{GILLY, Daniel. "'E como melhor no fim trabalho perdido e silêncio': A experiência histórica de Fim de Partida, de Samuel Beckett". Viso: Cadernos de estética aplicada, v. 13, nº 25 (jul-dez/2019), p. 66-90.}

DOI: 10.22409/1981-4062/v25i/323

Aprovado: 09.11.2018. Publicado: 30.12.2019.

(C) 2019 Daniel Gilly. Esse documento é distribuído nos termos da licença Creative Commons Atribuição-NãoComercial 4.0 Internacional (CC-BY-NC), que permite, exceto para fins comerciais, copiar e redistribuir o material em qualquer formato ou meio, bem como remixá-lo, transformá-lo ou criar a partir dele, desde que seja dado o devido crédito e indicada a licença sob a qual ele foi originalmente publicado.

Licença: http://creativecommons.org/licenses/by-nc/4.0/deed.pt_BR

Accepted: 09.11.2018. Published: 30.12.2019.

(C) 2019 Daniel Gilly. This document is distributed under the terms of a Creative Commons Attribution-NonCommercial 4.0 International license (CC-BY-NC) which allows, except for commercial purposes, to copy and redistribute the material in any medium or format and to remix, transform, and build upon the material, provided the original work is properly cited and states its license.

License: http://creativecommons.org/licenses/by-nc/4.0/ 
Fim de partida, de Beckett, coloca seu espectador diante de um cômodo com alguns poucos objetos: uma porta, à direita; um quadro, ao lado da porta; duas janelas, uma de cada lado; dois latões, no canto; e uma cadeira de rodas, no centro, onde se senta um homem cego com um lenço manchado de sangue aberto sobre o rosto. Não há nenhuma indicação sobre a localização deste cômodo ou mesmo sobre a época na qual se passa a ação, o que faz com que os poucos objetos e personagens dispostos em cena careçam de qualquer explicação sobre como chegaram ali ou sobre a quantidade de tempo em que estão nesta situação. Isto torna possível considerar a peça como um acontecimento sincrônico que ocorre sem qualquer relação com a história e que não reconhece a necessidade da existência de um progresso temporal. É uma peça que acontece fora do tempo e que pode se repetir infinitamente sem que qualquer coisa de novo aconteça. Nesse caso, não se pode buscar em Beckett a formulação clara de um posicionamento frente ao curso da história e dos acontecimentos, mas é a própria reprodutibilidade do mesmo que dá sinais sobre a experiência histórica expressa por suas obras.

As repetições sempre presentes em suas peças revelam a estrutura de sua particular percepção do tempo, marcada menos pela continuidade e progressão dramática de destinos individuais através de um fluxo temporal contínuo e abstrato, e mais pela própria imobilidade circular dentro da qual estes destinos permanecem confinados. Também em seus romances as séries e repetições não seguem a exigência de um sentido final, mas se determinam exclusivamente pela necessidade sem fins da estrutura lógica e irracional do pensamento fechado em si mesmo, como é o caso do episódio das pedras em Molloy e da comida oferecida aos cães em Watt. Nesses romances os próprios episódios se sucedem sem pretensão de desvelar a objetividade, sendo desencadeados pela própria estrutura conjectural da linguagem, prisão do pensamento. É dessas séries e repetições, e não da descrição do objeto, que se alimenta a narrativa do romance. Os episódios progridem sem que se possa estabelecer entre eles 
uma relação causal. Estão espaçados entre si e fragmentados, ligados apenas a fatos insignificantes a partir dos quais 0 pensamento desencadeia a trama. São livros inteiros compostos de digressões que existem apenas no pensamento e na estrutura linguística que o aprisiona, que se desencadeia no personagem a partir de fatos exteriores banais.

À banalidade do que é narrado se contrapõe um grande esforço mental que a ele se dedica. Os personagens de Beckett estão entregues a um momento histórico no qual a pura materialidade da existência se impõe como uma força paralisante e inescapável, como mostra o percurso de Molloy até a casa de sua mãe, marcado pelos sucessivos obstáculos físicos e ininteligíveis aos quais seu corpo é submetido. É assim que, ao contrário dos romances realistas com os quais Beckett dialoga, os narradores se afastam cada vez mais do mundo objetivo, que se torna excessivamente pesado, refugiando-se numa organização própria, interior, do pensamento que nada mais revela daquilo que é disposto externamente. 0 desenvolvimento da trama ocorre nesse recuo da realidade, que se tornou impenetrável e ameaçadora, e se reflete no próprio corpo do protagonista, na sua imobilidade e impotência. As contradições históricas do capitalismo da época de Beckett influíram para que ele rejeitasse a possibilidade de postular ainda um indivíduo autônomo com o poder de confrontar a realidade enquanto sujeito de saber e ação livres, e isso se manifesta formalmente em suas obras a partir desse abismo indevassável entre os domínios subjetivo e objetivo, entre a ilusória liberdade individual e a necessidade de submissão à objetividade.

Essa concepção de história coloca também problemas para o campo de sua produção dramática, já que o que Peter Szondi, por exemplo, classifica como "drama em seu estado mais puro" é completamente incompatível com ela. Em seu livro Teoria do drama moderno, Szondi formula três principais características da forma clássica do drama: o fato de ele se dar exclusivamente no presente, sem conhecer nenhuma determinação essencial ao seu movimento que pertença ao 
passado; a sua esfera intersubjetiva, ou seja, o fato de ser constituído pelo embate entre interesses e indivíduos autônomos; e a primazia do diálogo, que se coloca como instrumento primordial de realização do conflito dramático. ${ }^{1} 0$ que fica implícito nessa caracterização é que o drama deve constituir-se de uma situação na qual o conflito é avaliado na percepção imediata que os personagens têm dele no presente e resolvido de acordo com a capacidade racional e livre desses que se deparam com ele nessa imediatidade. De acordo com essa visão, o drama clássico baseia-se numa obstinada convicção no estatuto da liberdade humana e na capacidade de seu domínio sobre a matéria objetiva.

É justamente essa convicção que, segundo Szondi, torna-se insustentável a partir do final do século XIX, destruída pela emergência de materiais históricos incompatíveis com a forma dramática legada pela tradição. Na Europa da virada do século, a pura materialidade dos conflitos impostos pelo capitalismo revela como cada vez mais ilusória a pretensão de sua possível resolução racional, o diálogo se dissolve em indivíduos fragmentados que não compartilham um solo comum a partir do qual a comunicação é possível e o indivíduo se determina menos pela sua consciência e seu desejo do que pela mutilação à qual se submete nas fábricas e nas guerras. É nesse sentido que Theodor Adorno afirma que, em Beckett, "a ação, através de sua própria falta organizada de sentido, deve se conformar ao que aconteceu no teor de verdade do drama em geral". ${ }^{2}$ Ou seja, o absurdo de uma existência não experienciável deve ser incorporado na própria estrutura formal do drama do pós-guerra enquanto tal. Os elementos do drama tradicional sobrevivem na obra de Beckett apenas como restos:

Reconhecemos os elementos constituintes de cada gênero, mas eles já não funcionam mais como antes. Personagens não evoluem, a ação não caminha, conflitos não se resolvem, tendências sociais não se explicitam nos destinos individuais. Os esquemas seriais, cada vez mais frequentes na obra posterior de Beckett, ganham corpo frente à tradição erodida, e encaminham a sua produção para um terreno menos sondado, mas fértil para a 
exploração repetitiva da impotência de seus narradores. $^{3}$

Também significa dizer que os parâmetros para a criticabilidade da obra de Beckett não podem mais ser definidos pela pretensão de encontrar no drama a explicitação e afirmação de uma situação humana universalizável, representada através do conflito intersubjetivo: "Compreendê-la não pode significar outra coisa senão compreender a sua incompreensibilidade, reconstruir concretamente o contexto desta falta de sentido". ${ }^{4}$

O sujeito não é mais o centro deste drama situado no contexto do capitalismo tardio, não pode ser o seu tema e nem o seu catalisador, mas nele existe somente como resíduo das relações de produção vigentes. A compreensibilidade da peça teatral, que só seria possível se mediada pela existência desse sujeito capaz de conferir sentido para uma dada situação, fica comprometida na medida em que esse sujeito não pode mais ser suposto por uma essência racional do humano, mas como produto da história. $\mathrm{Na}$ análise de Adorno sobre a peça Fim de partida, o indivíduo perde suas possibilidades de definição a partir de qualquer concepção a-histórica de sujeito:

O indivíduo como categoria histórica, como
resultado do processo capitalista de
alienação e como protesto contra esse
mesmo processo, tornou-se claramente
efêmero [...] A imediatidade da individuação é
enganosa; aquilo ao qual a experiência
humana particular adere é mediado,
condicionado. Fim de partida insinua que a
reivindicação de autonomia e de existência
pelo indivíduo tornou-se inverossímil. [...] a
prisão da individuação se revela ao mesmo
tempo como prisão e como aparência. ${ }^{5}$

Nas peças teatrais de Beckett, portanto, os indivíduos são apresentados em conformidade com a sua situação histórica mais urgente. Isso não significa que o mundo factual penetra a obra de Beckett enquanto tema, mas que o processo histórico exige a representação de uma nova situação existencial dos sujeitos, dentro da qual eles não são mais os agentes da 
conformação artística, mas se submetem a métodos exteriores de composição. 0 que antes era o centro racional do espírito no drama se converte em matéria sem autonomia, entregue nas mãos de um poder incompreensível, assim como a natureza torna-se nada mais do que matéria-prima sob o processo de produção capitalista.

Completamente reduzidos a si mesmos, os sujeitos, um acosmismo tornado carne, nada mais são do que realidades insignificantes de seu mundo reduzido a dejeto, pessoas vazias através das quais ele só pode ressoar. Sua falsidade é o resultado da desmistificação do espírito como mitologia [...] a identidade pura transforma-se na identidade do aniquilado, identidade de sujeito e objeto em estado de alienação consumada. ${ }^{6}$

No que diz respeito à nova situação histórica do drama, isso quer dizer que não se pode mais eliminar da composição artística a reflexão sobre os mecanismos formais aos quais 0 antigo ser humano racional deve agora necessariamente se submeter. A reflexão sobre a artificialidade da construção dramática e a desconstrução do ideal de sujeito moderno é acompanhada pela identificação da personagem com o procedimento técnico para o qual ela é somente matéria abstrata. Para as personagens, isso significa que as ações são principalmente motivadas pelo caráter instrumental de sua composição dentro da estrutura do drama, e não pela exigência de representação de sentimentos ou ideias. Em Fim de partida, Hamm e Clov levam a peça adiante sem ter nenhuma motivação ou desejo próprio, completamente alheios às condições impostas pela construção dramática:

Clov: Por que esta comédia, todos os dias? Hamm: Rotina. Nunca se sabe. ${ }^{7}$

O modo como falam não provém de um posicionamento próprio, mas da posição que deles é esperada pela própria situação, à qual devem se adequar:

Clov: Pra que eu sirvo?

Hamm: Pra me dar as deixas. (Pausa) Avancei bastante a minha história. (Pausa) Está bem 
avançada a minha história. (Pausa) Pergunte até onde eu cheguei.

Clov: Ah, falando nisso, e a sua história?

Hamm: (muito surpreso) Que história?

Clov: Aquela que você conta desde sempre.

Hamm: Ah, você quer dizer o meu romance?

Clov: Isso.

Pausa.

Hamm: (com raiva) Continue, criatura, continue mais um pouco. ${ }^{8}$

Seu comportamento não é racional ou livre, a catástrofe de uma sociedade desfigurada os transformou em joguetes dentro de um contexto estranho, para onde foram arrastados e desfigurados pelas forças destrutivas da determinação capitalista. A sugestão de que as ações e diálogos poderiam conferir sentido para o desenrolar da peça é motivo de deboche:

Hamm: Clov! Clov: (irritado) Que é? Hamm: Não estamos começando a... a... significar alguma coisa? Clov: Significar? Nós, significar! (Riso breve) Ah, essa é boa! ${ }^{9}$

A continuidade da peça é angustiadamente experimentada como incompreensível e, ao mesmo tempo, como necessária, como algo que deve ter uma finalidade apesar de não levar a lugar algum:

Hamm: Isso anda meio sem graça. (Pausa) Mas é sempre assim no fim do dia, não é, Clov?

Clov: Sempre.

Hamm: É um fim de dia como os outros, não é, Clov?

Clov: Parece.

Pausa.

Hamm: (com angústia) Mas o que está acontecendo, o que está acontecendo?

Clov: Alguma coisa segue seu curso. ${ }^{10}$

Essa "coisa" indeterminada, que segue um curso também indeterminado, carrega Hamm e Clov para uma existência à qual devem se adaptar sem compreender, e que acaba por deformá-los física e espiritualmente. Para Adorno, o condicionamento imposto às personagens pelo contexto histórico equivale à situação de moribundos que devem se 
adequar à proximidade da morte ou à de animais submetidos a experimentos científicos: "As personagens de Beckett comportam-se de maneira primitiva e behaviorista em conformidade com as circunstâncias pós-catástrofe, e essa catástrofe as mutilou tanto que elas não podem agir de outra forma: moscas se contorcendo após serem meio esmagadas pelo mata-moscas". ${ }^{11}$ No Rei Lear, de Shakespeare, Gloucester afirmava que os humanos nada mais são do que moscas nas mãos dos deuses, morrendo esmagados por seus desígnios arbitrários. Ao motivo cósmico shakespeareano para o sofrimento das moscas, a existência de deuses eternos cujas vontades se chocam com os desejos terrenos, Adorno contrapõe a persistência, em Beckett, de uma catástrofe histórica, inseparável de uma situação histórica da humanidade na qual os deuses saíram de cena e deram lugar a um sofrimento inominado. Uma catástrofe que não é a morte fulminante, apenas um esmagar pela metade que mantém o agonizante vivo. Esta catástrofe perderia todo o seu sentido para a forma do drama se pudesse ser representada no palco a partir de um acontecimento histórico singular, pois a humanidade e a cultura não sobrevivem a ela e, portanto, também não podem localizá-la na realidade e dar-lhe forma artística:

Depois da Segunda Guerra Mundial tudo, até mesmo a cultura que ressurge, é destruído sem o saber; a humanidade continua vegetando e rastejando - depois de acontecimentos aos quais nem os sobreviventes podem sobreviver - sobre um monte de destroços, tornando pueril a autorreflexão sobre o estado de sua própria destruição [...] Indiferenciável é a fase da reificação completa do mundo, a catástrofe permanente, que não deixa mais sobrar nada que não tenha sido feito pelos homens; e mais um processo catastrófico causado pelos próprios homens, no qual a natureza foi exterminada e depois disso nada mais cresce. [...] O fim do mundo é deduzido como se fosse óbvio. Qualquer suposto drama da era atômica seria chacota de si mesmo, sobretudo porque sua fábula distorce confortavelmente 0 horror histórico do 
anonimato, situando-o nos caracteres e ações dos homens. [...] A violência do indizível é imitada pela timidez em mencioná-lo. Beckett o mantém nebuloso. Apenas eufemisticamente pode-se falar sobre o que é incomensurável a toda experiência, assim como se fala do assassinato de judeus na Alemanha. $^{12}$

A violência anônima e indizível que dá forma aos personagens de Beckett é também uma violência onipresente, não podendo ser situada em nenhum momento específico das peças (e nem da história, como numa catástrofe ambiental ou numa guerra nuclear). É por isso que Fábio de Souza Andrade chama esta catástrofe de um evento "quase mítico"13, e aponta para a abundância de elementos mitológicos na obra teatral de Beckett, mesmo que profanados ou desfigurados: "Como os romances da trilogia, inclui uma infinidade de alusões mitológicas (bíblicas, históricas, literárias) sem se deixar reduzir a uma interpretação alegórica restrita, alimentada por correspondências biunívocas entre seu enredo e apenas um destes mitos em especial". ${ }^{14}$ Bíblia, história e literatura se intrincam produzindo referências mitológicas que não resultam mais em sentido e orientação. Em Esperando Godot, Vladimir evoca a passagem bíblica da crucificação de Cristo para alimentar a esperança de alguma salvação possível: "Um dos ladrões foi salvo. (Pausa) É uma estatística razoável". ${ }^{15}$ Mas logo depois a palavra sagrada é questionada segundo os termos de sua verificabilidade, da possibilidade de seu valor informativo enquanto um relato histórico: "Como é possível que, dos quatro evangelistas, só um fale em ladrão salvo? Todos quatro estavam lá - ou por perto - e apenas um fala em ladrão salvo. [...] Todos quatro estavam lá. E só um fala em ladrão salvo. Por que acreditar nele e não nos outros?"16 Rebaixada a mera informação, relato de um observador cujo ponto de vista é questionável, a promessa de salvação anunciada na Bíblia converte-se, no melhor dos casos, em incerteza; no pior, em mentira, ilusão de que a punição e o castigo eterno do inferno possam um dia ser redimidos: "O povo é de uma burrice"17, diz Estragon, que ignorava a 
passagem e por isso não coloca em questão a impossibilidade de ser salvo.

O material mítico utilizado serve ao autor para apresentar a passagem do tempo como um domínio inexplicável e ininteligível que determina as personagens, sendo que $o$ material histórico, ao se misturar com estas referências, perde sua qualidade diacrônica e torna-se irreconhecível e irremediável: "A história é omitida, pois ela mesma ressecou a força da consciência de pensar a história, a força de rememorar. 0 drama se silencia em gesto, petrificado no meio dos diálogos. Da história aparece apenas o seu resultado como declínio". ${ }^{18} \mathrm{Na}$ confusão de história e mito presente nos textos beckettianos confirma-se a incerteza sobre a existência de um passado (mítico ou histórico) capaz de dar sentido à situação presente e ao desenrolar da trama das próprias peças. 0 esquema tradicional de um conflito que se resolve no final da obra, que é de algum modo uma espécie de reelaboração do mito da salvação cristã, dá lugar a um passar do tempo que em nada contribui para o desenrolar dos destinos individuais.

A catástrofe posta em cena não pode ser o vindouro apocalipse bíblico, algo definitivo que dá sentido a tudo o que ocorreu antes, mas também não se reduz a um evento passado qualquer que ainda permitiria a continuidade da vida: "Se a catástrofe se resumisse a um apocalipse parcial, seria uma piada de mau gosto: a natureza, da qual os reclusos estão isolados, está como se não existisse mais; o que resta dela apenas prolonga o sofrimento" ${ }^{19}$ Não é só a cultura que é destruída, mas a própria natureza é atingida e se retira de cena. Não pode mais ser associada à possibilidade de renovação e de frescor, já que, aniquilada pela catástrofe, se mostra apenas nas suas propriedades degenerativas. Em Fim de partida, Hamm narra o episódio de um pintor louco que vê por trás de toda beleza da natureza a sua progressão em direção ao pó, a morte contida no florescimento e na juventude:

Conheci um louco que pensava que o fim do mundo tinha chegado. Ele pintava. Eu gostava muito dele. la vê-lo no hospício. Eu o tomava 
pela mão e o arrastava até a janela. Olhe! Ali! $\mathrm{O}$ trigo começa a brotar! E ali! Olhe! As velas dos pesqueiros! Como é bonito! (Pausa) Ele me fazia soltar sua mão, bruscamente, e voltava para o seu canto. Apavorado. Tinha visto apenas cinzas. (Pausa) Apenas ele tinha sido poupado. (Pausa) Esquecido. Parece que o caso não é... não era... tão... tão raro. ${ }^{20}$

Hamm continuamente manda Clov olhar pelas janelas para contemplar o que resta de natureza ao redor do abrigo em que os dois vivem. As respostas sempre enfatizam a mesma morte e a putrefação do mundo: "Como tudo está? Em uma palavra? É isso que quer saber? Só um segundo. (Dirige a luneta para o exterior, olha, abaixa a luneta, volta-se para Hamm) Cadavérico". ${ }^{21}$ A face cadavérica da natureza impede que se imagine uma possibilidade de vida fora do abrigo. "Fora daqui é a morte", diz Hamm. ${ }^{22}$ Por isso, à degradação presente no desdobramento temporal da peça corresponde também uma degradação da mobilidade espacial, marca característica de tantos personagens atrofiados de Beckett. Em Fim de partida, Nagg e Nell perderam as pernas e vivem em dois latões no canto do palco, enquanto que Hamm é cego e usa uma cadeira de rodas. $O$ único que ainda pode andar é Clov (ainda que com restrições), e mesmo ele se mostra incapaz de deixar a casa durante toda a peça. De qualquer modo, também Clov está destinado a se deteriorar até perder toda a mobilidade, como diz a profecia de Hamm:

Na minha casa. (Pausa. Tom profético, com volúpia) Um dia você ficará cego, como eu. Estará sentado num lugar qualquer, pequeno ponto perdido no nada, para sempre, no escuro, como eu. (Pausa) Um dia você dirá, estou cansado, vou me sentar, e sentará. Então você dirá, tenho fome, vou me levantar e conseguir o que comer. Mas você não levantará. E você dirá, fiz mal em sentar, mas já que sentei, ficarei mais um pouco, depois levanto e busco o que comer. (Pausa) Ficará um tempo olhando a parede, então você dirá, vou fechar os olhos, cochilar talvez, depois vou me sentir melhor, e você os fechará. $E$ quando reabrir os olhos não haverá mais parede. (Pausa) Estará rodeado pelo vazio do infinito, nem todos os mortos de todos os 
tempos, ainda que ressuscitassem, o preencheriam, e então você será como um pedregulho perdido na estepe. (Pausa) Sim, um dia você saberá como é, será como eu, só que não terá ninguém, porque você não terá se apiedado de ninguém e não haverá mais ninguém de quem ter pena. ${ }^{23}$

Mas se Clov vai se assemelhar a Hamm, o próprio Hamm vai se assemelhar a seu pai, Nagg, que também profetiza a deterioração do filho e a coincidência de seus destinos no futuro: "Não é impossível ver nos cotos de Nagg, ou na cegueira e paralisia de Hamm, estágios posteriores da limitação de Clov para se sentar e de sua dificuldade de locomoção. As profecias simetricamente atribuídas a Hamm e Clov lembram que o destino de todos é comum e sinistro". ${ }^{24} 0$ único desenvolvimento vislumbrado pela obra é o do envelhecimento e o da atrofia, nunca acompanhados de renovação. 0 mundo cadavérico exterior é reproduzido no interior do abrigo no aspecto cadavérico das personagens, para as quais corpo é sinônimo de declínio. A natureza destruída só continua a se manifestar, tanto no exterior como no interior da casa, na forma deste processo de decadência física e espiritual que leva tudo e todos à ruína.

\footnotetext{
Hamm: A natureza nos esqueceu. Clov: Não existe mais natureza. Hamm: Não existe mais! Que exagero! Clov: Nas redondezas.

Hamm: Mas nós respiramos, mudamos! Perdemos os cabelos, os dentes! A juventude! Os ideais!

Clov: Então ela não nos esqueceu. ${ }^{25}$
}

Continuar a partida em meio ao mundo da catástrofe contínua e da putrefação é uma maldição para Hamm e Clov, que esperam angustiadamente o fim que se desenrola na frente dos seus olhos: "Hamm: O fim está no começo e no entanto continua-se". ${ }^{26}$ Já a primeira fala da peça, de Clov, o anuncia ao mesmo tempo em que o aguarda com uma esperança incerta: "Acabou, está acabado, quase acabando, deve estar quase acabando". 27 Vale ressaltar que o processo diacrônico de deformação das personagens não ganha expressão no palco: 
Nagg e Nell já estão reduzidos a tocos no canto do palco, Hamm já está cego e paralisado e Clov já tem todas as suas restrições para se locomover. Tirando uma possível morte de Nell, que não é esclarecida ou afirmada, nenhuma das personagens passa por qualquer desenvolvimento visível ao longo da obra. 0 envelhecimento e o declínio marcam todos os personagens, mas o espaço cênico para que produzam qualquer coisa de diferente do mesmo que já ocorre desde sempre é negado no confinamento espacial e temporal da peça. Até mesmo à decadência é negada a oportunidade de progressão, ela se condensa no mesmo momento indeterminado que não passa e que é sempre igual. "Que horas são?", pergunta Hamm, "As mesmas de sempre", responde Clov. ${ }^{28} \mathrm{O}$ "Fim" de Fim de partida já está no começo da peça (ou antes), mas não se efetiva nem quando a peça acaba. 0 que se experiencia nele não pode ser nada transformador ou definitivo, como a mudança ou a morte, mas somente a espera sem sentido de algo que não pode ocorrer, pois já não resta mais nada para ocorrer. A constatação da demora no prolongamento do fim, ao invés de incitar à ação, abate e conduz à resignação.

\author{
Hamm: Você não está cheio disso? \\ Clov: Estou! (Pausa) Do quê? \\ Hamm: Desse... dessa... disso. \\ Clov: Desde sempre. (Pausa) Você não? \\ Hamm: (melancólico) Então não há razão para \\ que isso mude. \\ Clov: Pode acabar. (Pausa) A vida inteira as \\ mesmas perguntas, as mesmas respostas. ${ }^{29}$
}

E numa passagem similar mais à frente:

\author{
Hamm: Você não acha que isso durou o \\ bastante? \\ Clov: Acho! (Pausa) O quê? \\ Hamm: Esse... essa... isso. \\ Clov: Sempre achei. (Pausa) Você não? \\ Hamm: (abatido) Então é um dia como os \\ outros. \\ Clov: Enquanto durar. (Pausa) A vida toda as \\ mesmas tolices. ${ }^{30}$
}

Os dias são iguais desde sempre, todos estão cansados deles, mas não existe nenhuma razão para que se tornem diferentes. 
A natureza nos esqueceu e no entanto continua atuando, não produzindo mais qualquer interação com a vida humana, mas perpetuando sua existência. A vida em seu estado bruto, a simples sobrevivência, se mantém precariamente, enquanto que a vida humana, condenada ao palavrório sem fim que repete sempre as mesmas perguntas, as mesmas respostas e as mesmas tolices, é comparada a uma praga. Qualquer possibilidade de que ela venha a se reconstituir deve ser eliminada em sua raiz. Como ela agora se reduz a um punhado de carne sem história, essa renovação poderia surgir até mesmo da procriação dos ratos e das pulgas.

Clov: (angustiado, se coçando) Acho que é uma pulga!

Hamm: Uma pulga! Ainda há pulgas?

Clov: (se coçando) A não ser que seja um piolho.

Hamm: (muito perturbado) Mas a humanidade poderia se reconstituir a partir dela! Pegue-a, pelo amor de Deus!

Clov: Vou buscar o pó.

Sai.

Hamm: Uma pulga! É apavorante! Que dia!

Entra Clov com o pulverizador.

Clov: Voltei com o inseticida.

Hamm: Que ela tenha o seu quinhão! ${ }^{31}$

Toda criatura viva que entra em cena deve ser eliminada, por medo de que a mera existência de um ser vivo possa prolongar o fim. Depois da pulga, o próximo a ser eliminado é um rato que aparece na cozinha, e já no final da peça surge uma criança, figura que habitualmente poderia ser associada à esperança e à renovação. ${ }^{32}$

\footnotetext{
Clov: Ai, ai, ai!

Hamm: É uma folha? Uma flor? Um toma... (boceja)... te?

Clov: (olhando) Tomate coisíssima nenhuma! Uma pessoa! É alguém!

Hamm: Ah bom. Vá exterminá-lo. (Clov desce)

Alguém! (Vibrante) Cumpra seu dever! $!^{33}$
}

Mas Hamm volta atrás e a ação, novamente, não se desenrola para fora do abrigo: 
Hamm: Não vale a pena.

Clov pára.

Clov: Não vale a pena? Um procriador em potencial?

Hamm: Se ele existe, virá até aqui ou morrerá por lá. E se não existe, não vale a pena. ${ }^{34}$

Assim como a pulga, que desapareceu, e o rato, que fugiu, a criança não chega a ser exterminada. Quando Hamm pergunta se Clov matou o rato, ele diz que apenas pela metade, pois fora interrompido. 0 cachorro de pelúcia que Clov está confeccionando também está inacabado, ainda faltando uma pata, o sexo e uma fitinha, assim como o romance de Hamm, que segundo ele está perto de seu fim. No palco, não se consegue matar, morrer ou terminar qualquer coisa. Por incapacidade ou cansaço não se consegue chegar ao fim de nada, mesmo que este seja sentido como absolutamente necessário. Hamm diz: "Chega, está na hora disso acabar, no abrigo também. (Pausa) E mesmo assim eu ainda hesito em ter um... (boceja)... fim. É, é isso mesmo, está na hora disso acabar e mesmo assim eu ainda hesito em ter um... (boceja)... fim" ${ }^{35}$ Mas o que ele indica ser uma hesitação sua faz parte da própria necessidade imposta pela peça, a de fazer continuar a ação a despeito da falta de qualquer desenvolvimento nela. Mais à frente, o mesmo Hamm vai reformular este pensamento atribuindo ao fim a sua devida exterioridade: "Será o fim então e me perguntarei por que chegou o fim, por qual... (hesita)... por que motivo demorou tanto. (Pausa) Lá estarei eu, no velho refúgio, sozinho contra o silêncio e... (hesita)... a inércia" ${ }^{36} \mathrm{E}$ também Clov sabe que o curso daquilo que se apresenta desenrola-se à revelia de qualquer ação e compreensão sua. Quando a cortina finalmente baixar, não o fará de acordo com qualquer conexão causal com o que se representou antes, será um evento arbitrário que resiste à expressão em signos de linguagem: "Bem, isso nunca acabará, nunca vou partir. (Pausa) E então, um dia, de repente, acaba, muda, não entendo nada, morre, ou morro eu, também não entendo. Pergunto às palavras que sobraram: sono, despertar, noite, manhã. Elas não têm nada a dizer". ${ }^{37}$ 
No final da peça já está claro que não se pode deixar o abrigo, o que significaria a morte e a perspectiva de um fim, de uma ação acabada. As palavras que significam este fim também ficam pelo meio do caminho, não podendo alcançar o acontecimento e dar-Ihe forma definitiva. A linguagem se reduz a restos de pensamentos e ideias desconexas que nada mais significam. Mas ao contrário das outras criaturas que invadem a cena - o rato, a pulga e a criança -, que não se mostram e não falam, as quatro personagens não podem abrir mão da linguagem, têm que continuar falando e por continuarem falando não podem dar fim a nada: "Se puder me calar, e ficar em paz, estará acabado, todo som, todo movimento" ${ }^{38}$ Apesar dessa esperança vaga, é o próprio Hamm que insiste em continuar o diálogo, frequentemente gritando ("Clov!") e soando o apito que traz o seu interlocutor de volta à cena e à troca inútil de palavras: "Hamm de Fin de partie encarna de maneira paradigmática este vínculo entre proferir um discurso, ainda que mecânico e inócuo, e continuar existindo, o que para ele acaba por soar como uma maldição". ${ }^{39} \mathrm{E}$ assim como essa sobrevivência material é precária, o discurso que profere é igualmente pobre de coerência e orientação. Os textos dramáticos ditos pelas personagens de Beckett "dissolvem os projetos em palavrório, burburinho, rumor, ordenado e simétrico sim, mas que se reconhece e se mostra inútil, pondo em cena heróis armados de uma razão tortuosa e sem finalidade". ${ }^{40}$

As palavras de Hamm não passam de divagações que ficam no limiar entre a recordação e a ficção, tempo e narrativa incertos evocados pela pura afetação do tédio ocioso. 0 pensamento posto em cena não tem um sentido reto que resulte em qualquer coisa: "Clov: (triste) Nunca ninguém pensou de modo mais tortuoso como nós". ${ }^{41}$ No entanto, existe uma tensão entre a forma da composição simétrica e ordenada das peças (como na correspondência entre os dois atos em Esperando Godot e na retomada de temas, frases e ações em diversas etapas de Fim de partida) e a razão tortuosa e fragmentária que caracteriza o pensamento de Hamm, Clov, Didi, Gogô, etc. 0 corpo humano resiste à incorporação completa pelo processo técnico e racional sem finalidades que o aprisionou. 
Em Ato sem palavras I, um ator é lançado pela direita ao centro do palco, um deserto com luz ofuscante. Ouve um assobio à direita, de onde veio, e vai em sua direção. É novamente lançado violentamente para o centro do palco. Ouve agora um assobio à esquerda e vai em sua direção, sendo novamente lançado violentamente para o centro do palco. Ouve novamente um assobio à esquerda, mas dessa vez o condicionamento imposto pelo processo foi bem sucedido, e ele não vai em direção ao som. Fica imóvel no centro do palco, refletindo e olhando para as mãos, posição que assumirá durante vários momentos da curta peça. A partir daí, o assobio passa a anunciar a entrada em cena de objetos que o retiram deste estado, através da promessa de realização de um desejo material que, no entanto, nunca se concretiza. 0 primeiro objeto anunciado é uma árvore, carregada para o fundo do palco por cordas, e que projeta uma sombra no chão. Mas no momento em que o homem se senta sob ela, suas folhas se fecham e a sombra desaparece. A mesma frustração ocorre após o assobio anunciar que uma garrafa de água tinha sido posta em cena, suspensa no ar por uma corda a alguns metros do chão, inalcançável. Cubos de madeira são lançados em cena para que ele tente alcançar a garrafa subindo neles, mas a cada tentativa a garrafa sobe mais um pouco e torna-se novamente inalcançável. Nos intervalos do assobio, que se dão quando uma empresa qualquer falha, o homem volta a seu estado meditativo, olhando as mãos. Sua tentativa final é o suicídio com o auxílio de uma tesoura que entrou no palco, mas enquanto se prepara, a tesoura, presa a uma corda, é retirada do palco. Ele se senta em um dos cubos, mas este é puxado e o homem é lançado ao chão, onde permanece deitado de lado até a cortina cair. A garrafa com água desce até quase tocar seu rosto, mas ele não faz mais nenhum esforço para agarrá-la. Sua última ação é olhar para as mãos. ${ }^{42}$

O estado final do ator reproduz uma atitude característica dos personagens de Beckett, a inércia como condição histórica natural de quem foi esmagado pela engrenagem da produção industrial. A ele só resta a reflexão silenciosa, que o retira do mundo e cria um estranhamento da realidade e do próprio 
corpo, das mãos que não se mostram mais instrumentos capazes e que são agora observadas com espanto. Se por um lado a existência humana passa a se assemelhar àquela de ratos de laboratório, que agem em resposta a estímulos impostos por uma necessidade externa (a disposição cênica, a técnica do dramaturgo, etc.), a necessidade de pensamento, verbalizado ou não, produz uma contradição com a cena que deixa claro o descompasso entre a situação e a posição ocupada pelo corpo dentro dela.

Beckett apresenta no palco um conflito análogo ao que se apresenta na sociedade, na absorção de todas as esferas de vida pela racionalidade sem fins do capitalismo tardio. 0 comportamento humano convertido em abstração cientificamente manipulável surge como instrumento de adequação violenta e alienada ao modo de funcionamento dos meios de produção. 0 drama pode mostrar a não coincidência fundamental entre este processo e o que ainda resta de humanidade depois dele, mas não tem o poder de sugerir nenhum rompimento com essa ordem. Dela nem mesmo a morte pode escapar, pois ela já não confere mais sentido nem para a vida pregressa daquele que morre, e nem para aqueles que sobrevivem a ela. É por isso que as peças de Beckett se negam a representar, na maioria das vezes, a morte enquanto acontecimento. Isso não significa que ela se ausenta do palco, mas que, ao contrário, sua onipresença torna o evento individual dispensável:

Clov: Você acredita na vida depois da morte? Hamm: A minha sempre foi. ${ }^{43}$

$\mathrm{Na}$ existência fantasmagórica destas personagens os estratos de tempo se confundem, deixando a realidade sem explicação histórica ou racional, como uma exterioridade impenetrável: "A consciência se encontra diante de uma multiplicidade temporal que lhe torna impossível fixar-se num ponto que permitiria uma perspectiva para a recapitulação de sua realidade de vida. Visão, sonho, lembrança, esperança e o agora 'real' não podem ser separados" ${ }^{44} \mathrm{~A}$ grande dificuldade para os personagens de Beckett é dar a essa exterioridade alguma ordenação racional 
que possa ser efetivamente assimilada pela experiência e prover uma direção e um sentido. A consciência de heróis como os de Fim de partida, que não podem mais diferenciar em suas falas os discursos ficcionais das lembranças ou dos fatos ocorridos no passado e no presente, confere novamente à realidade a expressão de um direito quase mítico, cujo fundamento foi esquecido na senilidade de consciências mutiladas que o perseguem desorganizadamente.

J. M. Coetzee compara a barreira de significação que se coloca na frente das personagens beckettianas à barreira de significação imposta ao capitão Ahab, do Moby Dick de Melville. Para Coetzee, o que está em jogo nos dois autores é a questão de saber se somos parte de um experimento governado por uma inteligência insondável ou se, ao contrário, estamos submetidos a uma realidade sem regras na qual não há esquema algum do qual fazemos parte. ${ }^{45}$ Essa pergunta se coloca nos dois casos porque em ambos a realidade aparece coberta por uma parede que barra o avanço da razão. Segundo Ahab, em Moby Dick, todos os objetos visíveis do mundo não são nada além de "máscaras de papelão", que encobrem o sentido do real dando-lhe uma face irreconhecível, uma parede que impede um prisioneiro de passar ao outro lado de sua cela. É assim também que Ahab vê o seu desejo, a baleia branca, como uma "parede, empurrada até a mim. Às vezes eu penso que não há nada além dela". ${ }^{46}$ Nada existe para Ahab além da baleia branca, e o mero mistério de sua existência consome todos os seus esforços e desejos.

No interior de seu abrigo, Hamm toca, impotente, a parede, pois sabe que nada ganharia mesmo se pudesse ultrapassá-la: "Velha parede! (Pausa) Além é... o outro inferno". ${ }^{47}$ Não há mais nada além dela do que o inferno, frente ao qual a inteligência se retrai, sobrevivendo como patrimônio cultural confinado no espaço interior. Os dois, Hamm e a inteligência humana, de quem ele se sente o guardião por excelência, são os únicos restos de uma humanidade que não pode mais sobreviver, ambos se atrofiando até a morte. A parede representa o limite máximo dentro do qual ainda é permitido se entregar ao inútil e 
vazio pensamento sem fins. O capitão Ahab, no entanto, não se deixa impedir pelo reconhecimento da existência da parede e da negação que esta representa para o pensamento:

\begin{abstract}
Mas em cada acontecimento - no ato vivo, na ação indubitável -, há ali algo desconhecido, mas ainda assim racional, que projeta os contornos de seu rosto por detrás da máscara irracional. Se um homem vai atacar, que ataque através da máscara! Como pode um prisioneiro alcançar o exterior a não ser se atirando através da parede $?^{48}$
\end{abstract}

Como diz Coetzee, Ahab vai prosseguir até atravessar, ou ser atravessado, por esta outra inteligência, uma que reconhece como estranha e que é aparentemente impenetrável. Onde Hamm vê um limite intransponível, Ahab vê a possibilidade de um pensamento e um sentido que não se reduzem ao mero raciocínio lógico e que por isso não podem ser sistematizados e compreendidos pela razão pura. Ahab lança seu arpão contra a baleia, e a grande parede branca sangra diante dos olhos de todos: "Não se pode escapar de seu sangue. Seu sangue borbulha e ferve por metros, até que os raios do sol, refletidos por ele, pintam de vermelho os rostos de seus assassinos". ${ }^{49} \mathrm{~A}$ realidade é afetada, mesmo que apenas por uma leve alteração de cor. Mas Hamm e Clov não podem atravessar a parede, o único sangue que veem está no lenço manchado que cobre o rosto de Hamm, mancha seca já presente antes de a cortina subir e que não parece ter sido resultado da ação de alguém. "Em suas celas brancas, os eus de Beckett, suas inteligências, suas criaturas, seja lá como se prefere chamá-los, esperam e olham e observam e anotam". 50

Por que estas criaturas não pegam seu arpão e o arremessam através da parede branca? Resposta: Porque são impotentes, inválidos, aleijados, acamados. Porque são cérebros presos em potes sem braços e pernas. Porque são vermes. Porque não têm arpões, apenas lápis, no máximo. Porque eles são aleijados ou inválidos ou vermes ou mutilados armados no máximo com lápis? Porque eles e a inteligência por trás deles acreditam que a única ferramenta capaz de perfurar a parede branca é a ferramenta do pensamento puro. 
Apesar de seus olhos provarem que a ferramenta do pensamento puro falha de novo e de novo e de novo. Você deve continuar. Não posso continuar. Continue. Tente de novo. Falhe de novo. ${ }^{51}$

Volta à mente a recorrência do corpo deitado ou sentado no escuro, completamente sozinho. 0 pensamento que é expresso em cena prescinde de corpo, ação e companhia. Ele afasta todas as possibilidades violentamente e calmamente prepara o palco para a encobrimento de seu próprio corpo e o recuo definitivo em direção ao escuro. A experiência histórica enformada pela obra de Beckett é a de uma prisão construída pela razão e pela própria experiência fracassada do progresso histórico europeu. Faltam mecanismos capazes de inserir o corpo como mediador de um saber e sujeito de uma experiência não alienada de mundo porque a própria linguagem se reconhece como aquilo que aprisiona o corpo. $\mathrm{Na}$ prosa tardia e nas peças tardias de Beckett criatura e criador se confundem, todo personagem é prisioneiro da criação, mesmo que esta seja criada por ele mesmo. Criar torna-se ao mesmo tempo produzir a própria prisão da linguagem e do mecanismo literário.

Você agora deitado de costas no escuro não irá erguer-se de novo para apertar as pernas com os braços e abaixar a cabeça até não poder abaixá-la mais. Mas com o rosto voltado para cima de vez trabalhar em vão na sua fábula. Até finalmente ouvir como as palavras estão chegando ao fim. Com cada palavra inane um pouco mais perto da última. E como a fábula também. A fábula de alguém com você no escuro. A fábula de alguém fabulando de alguém como você no escuro. $E$ como melhor no fim trabalho perdido e silêncio. E você como sempre esteve.

Sozinho. ${ }^{52}$

Daniel Gilly é doutorando em filosofia na UNIFESP.

${ }^{1}$ SZONDI, P. Teoria do drama moderno. Tradução de Luiz Sérgio Repa. São Paulo: Cosac \& Naify, 2001, pp. 29-34. 
2 ADORNO, T. "Versuch, das Endspiel zu verstehen" In: Gesammelte Schriften. Band 11. Frankfurt Am Main: Suhrkamp, 1999, pp. 282-283.

3 GATTI, L. "Samuel Beckett e o minimalismo". Texto debatido no IX Encontro do GT de Estética da ANPOF, PUC-RJ/IMS, 22 a 24 de maio de 2018, p. 7. Disponível em: www.fil.puc-rio.br/gtestetica/. Acessado em: 16.08.2018.

${ }^{4}$ ADORNO, T. Op. cit., p. 283.

${ }^{5}$ Ibidem, pp. 290-291.

${ }^{6}$ Ibidem, p. 293.

${ }^{7}$ BECKETT, S. Fim de partida. Tradução de Fábio de Souza Andrade. São Paulo: Cosac Naify, 2002, p. 80.

${ }^{8}$ Ibidem, pp. 114-115.

${ }^{9}$ Ibidem, p. 81.

${ }^{10}$ Ibidem, p. 55.

${ }^{11}$ ADORNO, T. Op. cit., p. 293.

${ }^{12}$ Ibidem, pp. 285-286.

${ }^{13}$ ANDRADE, F. de S. Samuel Beckett: o silêncio possível. São Paulo: Ateliê Editora, 2001, p. 89.

${ }^{14}$ Ibidem, p. 96.

${ }^{15}$ BECKETT, S. Esperando Godot. Tradução de Fábio de Souza Andrade. São Paulo: Cosac Naify, 2014, p. 31.

${ }^{16}$ Ibidem, pp. 33-34.

${ }^{17}$ Ibidem, p. 34.

${ }^{18}$ ADORNO, T. Op. cit., p. 288.

${ }^{19}$ Ibidem, p. 286.

${ }^{20}$ BECKETT, S. Fim de partida. Op. cit., p. 97.

${ }^{21}$ Ibidem, pp. 76-77.

${ }^{22}$ Ibidem, p. 48.

${ }^{23}$ Ibidem, p. 86.

${ }^{24}$ ANDRADE, F. de S. Op. cit., p. 100.

${ }^{25}$ BECKETT, S. Fim de partida. Op. cit., pp. 51-52.

${ }^{26}$ Ibidem, p. 128.

${ }^{27}$ Ibidem, p. 38.

${ }^{28}$ Ibidem, pp. 40-41.

${ }^{29}$ Ibidem, p. 42.

${ }^{30}$ Ibidem, pp. 98-99.

${ }^{31}$ Ibidem, p. 82. 
${ }^{32}$ É, por exemplo, a interpretação de Martin Esslin, que sugere: "Não será esse menino um símbolo da vida que existe fora do circuito fechado do afastamento da realidade?" ESSLIN, M. O teatro do absurdo. Tradução de Bárbara Heliodora. Rio de Janeiro: Zahar Editores, 1968, p. 64.

${ }^{33}$ BECKETT, S. Fim de partida. Op. cit., p. 140.

${ }^{34}$ Ibidem, p. 142.

${ }^{35}$ Ibidem, p. 39.

${ }^{36}$ Ibidem, pp. 128-129.

${ }^{37}$ Ibidem, p. 145.

${ }^{38}$ Ibidem, p. 129.

${ }^{39}$ ANDRADE, F. de S. Op. cit., p. 105.

40 Ibidem.

${ }^{41}$ BECKETT, S. Fim de partida. Op. cit., p. 52.

42 Idem. "Act Without Words" In: The Complete Dramatic Works. London: Faber and Faber, 2012 [e-book].

${ }^{43}$ Idem. Fim de partida. Op. cit, p. 104.

44 LEHMANN, Hans-Thies. Teatro pós-dramático. Tradução de Pedro Süssekind. São Paulo: Cosac Naify, 2007, p. 301.

${ }^{45}$ COETZEE, J. M. "Eight Ways of Looking at Samuel Beckett" In: Late Essays. Sidney: Kopf, 2017 [e-book].

${ }^{46}$ MELVILLE, H. Moby Dick. New York: Signet Classic, 1998, p. 157.

${ }^{47}$ BECKETT, S. Fim de partida. Op. cit., p. 71.

${ }^{48}$ MELVILLE, H. Op. cit., p. 157.

${ }^{49}$ COETZEE, J. M. Op. cit.

${ }^{50}$ Ibidem.

${ }^{51}$ Ibidem.

${ }^{52}$ BECKETT, S. "Companhia" In: Companhia \& outros textos. Tradução de Ana Helena Souza. São Paulo: Editora Globo, 2012, pp. 62-63. 